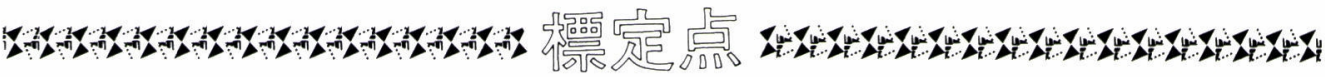

\section{Geo-informatics による複合生態フィールド科学の構築}

\author{
斎藤元也（東北大学大学院農学研究科附属複合生態フィールド教育研究センター副センター長）
}

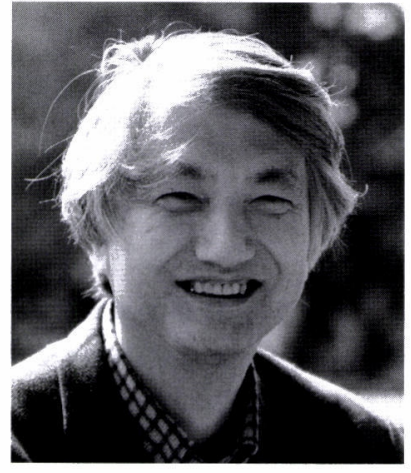

1988年の ISPRS 京都から 20 年たち，今年は ISPRS 北京2008の開催年です。10年一昔と言いますから二昔 前で, ISPRS 京都を知らない世代の方も多いと思われ ます。当時私は, 栃木県にある草地試験場に勤務し, リモートセンシング (RS) に関係していましたので, このISPRS 京都は良く知っておりましたが, 残念な がら参加しておりません。参加しておくべきだったと 深く反省しています。本年 7 月の ISPRS 北京 2008 に は，若い本学会諸兄にはできるだけ参加して頂きたい と思います。

私は33年前に農林省北海道農業試験場に採用にな ク, ほぼ同時期に日本写真測量学会に入会させて頂い ています。畑作物の分光測定, 赤外カラー空中写真に よるテンサイ (砂糖大根) の生育診断等の仕事をしま した。26年前に栃木県にある農水省草地試験場に移り， JICA プロジェクトのインドネシア農業 RS 計画への 参加, 衛星デー夕による草地抽出, PCによる農業リ モートセンシング解析システム構築などを行いまし た。19年前に農水省農業環境技術研究所に移り, 衛星 データによるタイの農業把握, RSによるフィリピン ピナツボ火山噴火被害把握等の仕事をして，5年前に 独立行政法人農業工学研究所に移り, 研究管理の仕事 を一年間行いました。

4 年前に, 東北大学大学院農学研究科附属複合生態 フィールド教育研究センターに農業 RS 分野の創設に 伴う教授募集と言うことで，東北大学に移りました。 この複合生態フィールド教育研究センターは, 宮城県

「写真測量とリモートセンシング」VOL. 47, NO. 1, 2008
鳴子町（現在：大崎市）にあった農場と同県女川町に あった海洋生物資源教育研究センターとが合併したの を契機に, RS を研究手法として複合生態フィールド 科学という新しい研究領域を作るということを指向し ました。この複合生態つィールド科学という発想はオ リジナルというわけではなく, 例えば, 京都大学で2003 年に森里海連環学として開講し, また, 地球圈一生物 圈国際協同研究計画 (IGBP) の沿岸域における陸域一 海域相互作用研究計画として1990年代前半からスター トしております。

地球や地域をRSやGISを駆使したGeo-Informaticsにより理解しようとする試みは, 1996年に国土 地理院が立ち上げた地球地図が最初であり，10年を経 て全体ができあがりつつあります。その後の1998年当 時のアル・ゴア米国副大統領がデジタルアースを提唱 しており，2001年に慶応大学福井先生がデジタルアジ アを提唱しておられます。私も2004年に東北大に着任 以来, 複合生態フィールド科学の仕事をデジタル複合 生態フィールドの構築と称して実施して扔ります。ま た，2005年に北大や酪農学園大関係者によるデジタル 北海道も動きだしました。この年は全球地球観測シス テム (GEOSS) 10年計画ができています。また，この 年に世界的に著名なグーグルマップ・グーグルアース ができましたが， 2 年前の 2003 年には, 国土地理院が 同様な「電子国土」を公開しています。

電子計算機というハードの性能アップを背景にソフ トウエアの発展も伴って, Geo-informatics 環境が簡 単に構築できる時代になったと言えます。この $\mathrm{Geo}^{-}$ informatics 環境を使い, 複合生態つィールド科学の 構築に残りの研究生活を費やしたいと考えています。 森林・草地・耕地・農村域・都市域・沿岸域・海洋々 いう複合生態つィールドの相互関係を, Geo-informaticsを駆使して, 少しでも明らかにしたいと言うと ころです。明確な研究戦略がある訳ではありませんが, 走りながら考えていきたいと思っています。日本写真 測量学会の皆様のご指導を宜しく抢願い致します。

今年の日本写真測量学会秋季学術講演会は, 仙台市 青葉区片平 2 丁目にある東北大学片平キャンパス内, 片平さくらホールで, 平成20年11月27-28日に開催予定 ですので，多数の方が仙台に来てくださることを期待 しております。 